\title{
Screening for microsatellite instability target genes in colorectal cancers
}

\author{
S Vilkki, V Launonen, A Karhu, P Sistonen, I Västrik, L A Aaltonen
}

J Med Genet 2002;39:785-789

See end of article for authors' affiliations

......................

Correspondence to:

$\operatorname{Dr} \mathrm{L}$ A Aaltonen,

Department of Medical

Genetics, PO Box 63

(Haartmaninkatu 8),

FIN-00014 University of

Helsinki, Finland;

lauri.aaltonen@helsinki.fi

*Present address:

European Bioinformatics

Institute, Wellcome Trust

Genome Campus, Hinxton,

Cambridge CB10 1SD, UK

Revised version received 28 June 2002

Accepted for publication

28 June 2002
Background: Defects in the DNA repair system lead to genetic instability because replication errors are not corrected. This type of genetic instability is a key event in the malignant progression of HNPCC and a subset of sporadic colon cancers and mutation rates are particularly high at short repetitive sequences. Somatic deletions of coding mononucleotide repeats have been detected, for example, in the TGF $\beta R I I$ and BAX genes, and recently many novel target genes for microsatellite instability (MSI) have been proposed. Novel target genes are likely to be discovered in the future. More data should be created on background mutation rates in MSI tumours to evaluate mutation rates observed in the candidate target genes.

Methods: Mutation rates in 14 neutral intronic repeats were evaluated in MSI tumours. Bioinformatic searches combined with keywords related to cancer and tumour suppressor or CRC related gene homology were used to find new candidate MSI target genes. By comparison of mutation frequencies observed in intronic mononucleotide repeats versus exonic coding repeats of potential MSI target genes, the significance of the exonic mutations was estimated.

Results: As expected, the length of an intronic mononucleotide repeat correlated positively with the number of slippages for both $G / C$ and $A / T$ repeats $(p=0.0020$ and $p=0.0012$, respectively). BRCA 1 , $C+B P 1$, and $R b 1$ associated $C$ tIP and other candidates were found in a bioinformatic search combined with keywords related to cancer. Sequencing showed a significantly increased mutation rate in the exonic A9 repeat of CHIP $(25 / 109=22.9 \%)$ as compared with similar intronic repeats $(p \leqslant 0.001)$.

Conclusions: We propose a new candidate MSI target gene CtIP to be evaluated in further studies.
G ermline mutations in at least five DNA mismatch repair genes (MSH2, MLH1, PMS1, PMS2, and MSH6) play a role in susceptibility to hereditary non-polyposis colorectal cancer (HNPCC). ${ }^{1-6}$ Defects in the DNA repair system lead to genetic instability and a mutator phenotype. This type of genetic instability is a key event in the malignant progression of HNPCC and a subset of sporadic colorectal cancers, and mutation rates are particularly high at short repetitive sequences. The phenomenon is called microsatellite instability (MSI) ${ }^{7-10}$

Deletions and insertions in coding region mononucleotide tracts lead to frameshift type mutations and to truncated protein products. Mutations in MSI target genes should give a growth advantage to cells carrying these defects, thus favouring their selection and subsequent formation of tumours. Approximately $90 \%$ of the DNA mismatch repair deficient colorectal carcinomas (CRCs) display mutations in the TGFBRII gene." Somatic deletions of coding mononucleotide repeats have been detected, for example, in the IGFIIR and BAX genes. ${ }^{12}{ }^{13}$ Also mononucleotide repeats in DNA mismatch repair genes MSH6 and $M S H 3$ have been found to be mutated. ${ }^{14}$ In previous works, TCF-4, CHK1, RIZ, MBD4, BLM, Caspase-5, PTEN, FAS, APAF-1, $B C L-10, R A D 50$, and WISP-3 have all been proposed to be MSI target genes. ${ }^{15-25}$ In addition, Mori et $a l^{26}$ and Park et $a l^{27}$ have recently proposed several novel candidates. Explorations of the genome for additional targets of MSI would increase understanding of the mutator pathway in human tumorigenesis.

Many studies have been carried out to identify new genes with somatic alterations in MSI tumours. According to Boland et al, ${ }^{28}$ MSI target genes should fulfil five criteria: a high mutational frequency, biallelic inactivation, a role in a growth suppressor pathway, alterations in MSI negative tumours also, and in vitro or in vivo functional evidence. These criteria have been discussed and the idea of haploinsufficiency has also recently been presented. ${ }^{29}{ }^{30}$ High mutational frequency and functional evidence have been accepted without ambiguity as criteria for novel MSI target genes.

By comparison of intronic mononucleotide repeats with exonic repeats of potential target genes, the significance of selection can be estimated, though a caveat to this approach is the varying mutation frequency in intronic mononucleotide repeats. ${ }^{31}$ Mutations in the intronic repeats are most likely not selected for because they typically do not have an effect on tumour development. Comparing the results of exonic repeats to these intronic controls and published data on mutation rates in other mononucleotide repeats of identical length should assist in showing the possible selection for mutated exonic mononucleotide repeats.

In this work we present our results on background mutation level in MSI tumours. We screened 14 intronic $(\mathrm{A} / \mathrm{T})_{6-9}$ and $(\mathrm{G} / \mathrm{C})_{6-9}$ mononucleotide repeats from MSI positive CRCs to gain more understanding on the background mutation rates of various repeats. In light of the results of this effort, two previously proposed MSI target genes with relatively low reported mutation frequencies, IGFIIR (G8) and $B L M$ (A9), were also scrutinised. In addition, bioinformatic searches were used to identify novel candidate MSI target genes. As a result of the search combined with keywords related to cancer, and subsequent laboratory analyses, a new candidate MSI target gene CtIP is proposed.

\section{MATERIALS AND METHODS}

Intronic mononucleotide repeats and known MSI target genes

First, monomorphic intronic mononucleotide repeats were screened from 93 MSI positive colorectal cancers derived from

Abbreviations: CRC, colorectal cancer; HNPCC, hereditary non-polyposis colorectal cancer; MSI, microsatellite instability 
Table 1 Intronic mononucleotide repeats were screened from 93 samples of tumour DNA of MSI positive colorectal cancer patients. $0-5.7 \%$ of samples were mutated in mononucleotide repeats and the length of an intronic mononucleotide repeat correlated positively with the number of slippages for both $G / C$ and $A / T$ repeats $(p=0.0020$ and $\mathrm{p}=0.0012$, respectively)

\begin{tabular}{lll}
\hline Intronic repeat & Gene (GenBank accession No) & Mutations \\
\hline G/C 6 & LPAP (CD45-binding protein) (X97267) & $0 / 93=0 \%$ \\
G/C 6 & Fast skeletal troponin T (TNNT3) (AFO26276) & $0 / 93=0 \%$ \\
G/C 7 & Human blood coagulation factor XII gene (M17466) & $2 / 93=2.2 \%$ \\
G/C 7 & Ciliary neurotrophic factor alpha receptor (HSCNFARO5) & $0 / 92=0 \%$ \\
G/C 8 & CMP-N-acetylneuramini acid hydroxylase (ABO09668) & $2 / 81=2.5 \%$ \\
G/C 9 & Regulatory factor 2 of sodium/hydrogen exchanger isoform A3 (AB016243) & $4 / 84=4.8 \%$ \\
& & \\
A/T 6 & Neurofibromatosis 1 (NF1) (AF004526) & $0 / 93=0 \%$ \\
A/T 6 & DNA topoisomerase II beta (TOP2B) (AF087143) & $0 / 93=0 \%$ \\
A/T 7 & LPAP (CD45-binding prot) (X97267) & $0 / 93=0 \%$ \\
A/T 7 & Leptin receptor (OBR) (U62501) & $0 / 93=0 \%$ \\
A/T 8 & DNA topoisomerase II beta (TOP2B) (AF087143) & $5 / 93=5.4 \%$ \\
A/T 8 & Chemokine receptor (CXCR-4) (AFO05058) & $0 / 93=0 \%$ \\
A/T 9 & EWS (AB016208) & $5 / 88=5.7 \%$ \\
A/T 9 & Osteonidogen (AB009814) & $4 / 93=4.3 \%$ \\
\hline
\end{tabular}

a population based series of 1044 colorectal cancers, ${ }^{32}{ }^{33}$ to determine the background mutation rate of $14(\mathrm{~A} / \mathrm{T})_{6-9}$ and $(\mathrm{G} / \mathrm{C})_{6-9}$ tracts in MSI tumours. Studied intronic mononucleotide repeats are shown in table 1. Second, previously recognised MSI target genes IGFIIR and BLM were scrutinised, because the reported mutation frequencies are relatively low (9.3\%-22\% and $16 \%-18 \%$, respectively). ${ }^{12} 1920$ The MSI status of the tumours had been determined by using the BAT26 mononucleotide marker. MSH2 mutations had been excluded by genomic sequencing, and MLHI mutations had been found from 17 cases. $^{32} 33$

PCR reactions of intronic mononucleotide repeats as well as IGFIIR were carried out in $10 \mu \mathrm{l}$ of reaction volume containing 50 ng genomic DNA, $10 \times$ PCR buffer (Applied Biosystems $(\mathrm{AB})$, Branchburg, NJ), $1 \mu \mathrm{mol} / \mathrm{l}$ of each primer, dCTP at 20 $\mu \mathrm{mol} / \mathrm{l}, 200 \mu \mathrm{mol} / \mathrm{l}$ each of dATP, dGTP, dTTP (Amersham Pharmacia Biotech, Piscataway, NJ), $0.7 \mu \mathrm{Ci}\left[\alpha-{ }^{32} \mathrm{P}\right] \mathrm{dCTP}$ (3000 Ci/mmol, Amersham Pharmacia Biotech UK Limited, Buckinghamshire, England), and 0.5 units of AmpliTaqGOLD polymerase (AB). The $\mathrm{MgCl}_{2}$ concentrations were 1.25-5 $\mathrm{mmol} / \mathrm{l}$. The following PCR cycles were used for amplification: $95^{\circ} \mathrm{C}$ for 10 minutes, 37 cycles of $95^{\circ} \mathrm{C}$ for 45 seconds denaturation, $59^{\circ} \mathrm{C}$ or $61^{\circ} \mathrm{C}$ for 30 or 45 seconds annealing, and $72^{\circ} \mathrm{C}$ for one minute extension. Final extension was $72^{\circ} \mathrm{C}$ for 10 minutes. Primer sequences and PCR conditions are available upon request. Ten $\mu \mathrm{l}$ of PCR product was mixed with $7 \mu \mathrm{l}$ loading buffer, and the 53-126 bp PCR products were run on $6.7 \%$ polyacrylamide gels; $0.6 \times \mathrm{TBE}$ was used as a running buffer in the gel run at a constant power of 80 watts. All aberrant bands were sequenced, and in all aberrant cases the corresponding normal DNA was analysed to confirm the somatic nature of the changes. The enzyme used in the PCR for sequencing was Pfu Turbo polymerase (Stratagene, La Jolla, CA), and the PCR products were about 200-300 bp in length. ABI PRISM Dye Terminator or ABI PRISM dRhodamine cycle sequencing ready reaction kit $(\mathrm{AB})$ were used for direct sequencing. Cycle sequencing products were electrophoresed on 6\% Long Ranger gels (FMC BioProducts) and analysed on an Applied Biosystems model 373A, 377 or 3100 automated DNA sequencer $(\mathrm{AB})$.

For sequencing BLM A9 mononucleotide repeats, the following touch down PCR cycles were used for amplification: $95^{\circ} \mathrm{C}$ for one minute, four cycles of $95^{\circ} \mathrm{C}$ for 45 seconds denaturation, annealing temperature $65-61^{\circ} \mathrm{C}$ for 45 seconds, and $72^{\circ}$ for 45 seconds extension, 30 cycles of $95^{\circ} \mathrm{C}$ for 45 seconds denaturation, annealing temperature $61^{\circ} \mathrm{C}$ for 45 seconds, and $72^{\circ} \mathrm{C}$ for 45 seconds extension. Final extension was $72^{\circ} \mathrm{C}$ for 10 minutes. Primer sequences are available upon request.

\section{Novel candidate MSI target genes}

Thirdly, we applied bioinformatic techniques to identify novel candidate MSI target genes. Human RNA sequences submitted after 1997 were extracted from GenBank (release 116) primate division. Entries with the word "partial" in the description were discarded in order to decrease the sequence redundancy. The annotated coding sequences (CDS lines in the feature table) were searched for mononucleotide tracts of 8 bp or longer. Medline identifiers from the sequence records containing those repeats were used to obtain Medline records. Title, abstract, and MeSH terms were searched for 83 manually selected keywords related to cancer. This approach resulted in the identification of 251 sequences. All the steps above with the exception of compiling the list of keywords were done automatically with a script written in PERL. Other searches were based on sequence homology to 34 known tumour suppressor or CRC related genes. Data are available on request. The list of 251 and 841 hits, respectively, was further scrutinised by eye to select a smaller subset of candidates. Eight possible new MSI target genes were studied by PCR and sequencing (table 2 ).

Screening for novel MSI target genes was performed with a set of 30 MSI positive CRCs by direct sequencing of the repeat region. PCR reactions were carried out in a $50 \mu \mathrm{l}$ reaction volume containing $150 \mathrm{ng}$ genomic DNA, $10 \times$ PCR buffer $(\mathrm{AB})$, $500 \mu \mathrm{mol} / \mathrm{l}$ of each dNTP (Finnzymes, Espoo, Finland), 1 $\mu \mathrm{mol} / \mathrm{l}$ of each primer, $1.25-5 \mathrm{mmol} / \mathrm{l}$ of $\mathrm{MgCl}_{2}$, and 5 units of AmpliTaqGOLD polymerase $(\mathrm{AB})$. The following PCR cycles were used for amplification: $95^{\circ} \mathrm{C}$ for 10 minutes, 37 cycles of $95^{\circ} \mathrm{C}$ for 45 seconds denaturation, annealing temperature for 45 seconds, and $72^{\circ} \mathrm{C}$ for 45 seconds extension. Final extension was $72^{\circ} \mathrm{C}$ for 10 minutes. The sequencing was performed as described earlier and the corresponding normal tissue DNA of the tumour cases with mutations was analysed. For CtIP, an additional 79 samples were sequenced (total 109 samples). Pfu Turbo proofreading polymerase (Stratagene) was used to confirm the nature of the mutations. Primer sequences, length of PCR fragments, annealing temperatures, and $\mathrm{MgCl}_{2}$ concentrations are listed in table 2 .

\section{Statistical analysis}

The independence and significance of correlation of mutation frequency with repeat length were estimated by logistic regression analysis. The occurrence/non-occurrence of mutation was considered as the dependent variable in each repeat length group. $\chi^{2}$ test statistic was used for other analyses. $\mathrm{p}<0.05$ was considered statistically significant. 
Table 2 Screening for eight candidate MSI target genes was performed in MSI positive CRCs. Primer sequences, length of PCR fragments, annealing temperatures, and $\mathrm{MgCl}_{2}$ concentrations are listed. Genes marked with $\bullet$ are from the search with keywords related to cancer, and genes marked with * from the tumour suppressor homology search

\begin{tabular}{|c|c|c|c|c|c|c|}
\hline $\begin{array}{l}\text { Gene (repeat) } \\
\text { (GenBank } \\
\text { accession No) }\end{array}$ & Function & Primer sequence & $\begin{array}{l}\text { Length of PCR } \\
\text { fragment (bp) }\end{array}$ & Annealing ${ }^{\circ} \mathrm{C}$ & $\begin{array}{l}\mathrm{MgCl}_{2} \\
(\mathrm{mmol} / \mathrm{I})\end{array}$ & Mutations \\
\hline $\begin{array}{l}\text { BCL10 (T7) } \\
(\mathrm{AFO97732) \bullet}\end{array}$ & Apoptotic signalling gene & $\begin{array}{l}\text { F: agc cac gaa caa cct ctc c } \\
\text { R: tgt aga tct ggt ggc aaa gg }\end{array}$ & 240 & 59 & 1.25 & $0 / 29=0 \%$ \\
\hline $\begin{array}{l}\text { PTP-BAS (A8) } \\
(\text { D2 1209)• }\end{array}$ & Protein tyrosine phosphatase & $\begin{array}{l}\text { F: tgg gat ttc tgt cca tca aag } \\
\text { R: caa cga cga tat gtg gca gt }\end{array}$ & 250 & 61 & 2.5 & $0 / 30=0 \%$ \\
\hline $\begin{array}{l}\text { CtIP (A9) } \\
\text { (U72066)• }\end{array}$ & $\begin{array}{l}\mathrm{C}+\mathrm{BP} \text { (phosphoprotein) binding } \\
\text { protein }\end{array}$ & $\begin{array}{l}\text { F: ttg tcc cct tct ctt tta cag c } \\
\text { R: ggg gct cca aat gtt tat ca }\end{array}$ & 274 & 61 & 2.5 & $25 / 109=22.9 \%$ \\
\hline $\begin{array}{l}\text { BAll (C7) } \\
\left(N M \_001702\right)^{*}\end{array}$ & $\begin{array}{l}\text { Brain specific angiogenesis } \\
\text { inhibitor }\end{array}$ & $\begin{array}{l}\text { F: tct gcg tgt cct cct cct ac } \\
\text { R: agg gca atg ttg cag aac tt }\end{array}$ & 346 & 59 & 2.5 & $0 / 30=0 \%$ \\
\hline $\begin{array}{l}\text { P73 (C6) } \\
(\text { AFO77616)* }\end{array}$ & p53 related protein & $\begin{array}{l}\text { F: gct gat gag gac cac tac cg } \\
\text { R: ctt cac acc ggc acc aag }\end{array}$ & 484 & 59 & 2.5 & $0 / 30=0 \%$ \\
\hline $\begin{array}{l}\text { GIOT-2 (T7) } \\
(\mathrm{ABO} 21642)^{*}\end{array}$ & Transcription repressor & $\begin{array}{l}\text { F: cgc tgg aaa gaa acc cta tg } \\
\text { R: aaa cag gga agg ctt tag aac a }\end{array}$ & 221 & 57 & 1.25 & $0 / 29=0 \%$ \\
\hline $\begin{array}{l}\text { PAIP (T6) } \\
\text { (AF013758)* }\end{array}$ & $\begin{array}{l}\text { Polyadenylate binding protein } \\
\text { interacting protein }\end{array}$ & $\begin{array}{l}\text { F: taa gcc cca ggt ggt tgt ag } \\
\text { R: caa cca ttc agg gtc tct gc }\end{array}$ & 228 & 61 & 2.5 & $0 / 30=0 \%$ \\
\hline $\begin{array}{l}\text { RIP3 (A6) } \\
\text { (NM_006871)* }\end{array}$ & $\begin{array}{l}\text { Receptor interacting } \\
\text { serine/threonine kinase }\end{array}$ & $\begin{array}{l}\text { F: tat ccc aga gtc agg cca ag } \\
\text { R: ctg aag atg tgc ctg ctg tc }\end{array}$ & 221 & 59 & 2.5 & $0 / 30=0 \%$ \\
\hline
\end{tabular}

\section{RESULTS AND DISCUSSION}

\section{Intronic mononucleotide repeats}

The results are summarised in table 1 . As expected, the length of an intronic mononucleotide repeat correlated positively to the number of slippages for both $\mathrm{G} / \mathrm{C}$ and $\mathrm{A} / \mathrm{T}$ repeats $(\mathrm{p}=0.0020$ and $\mathrm{p}=0.0012$, respectively). Compatible with previous findings, ${ }^{31}$ long $\mathrm{G} / \mathrm{C}$ repeats $(n \geqslant 8)$ were found to be more polymorphic than the respective A/T repeats. In general, the mutation frequencies were similar to the ones observed by Suzuki et al. ${ }^{34}$ To facilitate interpretation, we focused on repeats which were monomorphic in the germline. A/T 10 and $\mathrm{G} / \mathrm{C} 10$ repeats were typically polymorphic in the germline and were not included in this study. Multiple G8 and G9 repeats were tested to detect monomorphic ones, and this selection is a potential cause of bias towards inclusion of relatively stable repeats. However, Suzuki et $a l^{34}$ did not find any difference between the frequency of somatic mutations in polymorphic and monomorphic loci.

\section{Known MSI target genes}

Mutations in the G8 tract in the proposed MSI target gene IGFIIR were analysed in an MSI positive CRC panel of 92 cases. Mutations (+lbp/-1bp) of the coding G8 repeat were found in nine patients $(9.8 \%)$. This finding is similar to other studies $^{12}$ and the observed mutation rate was higher than in the intronic G8 repeat (2.5\%), but the difference did not reach significance. However, when taking into consideration the combined IGFIIR results from this and earlier studies (28/ $216=13 \%),{ }^{12} 2035$ IGFIIR mutation rate and intronic mutation rate were significantly different $(\mathrm{p} \leqslant 0.01)$.

IGFIIR is a cell surface receptor which allows a serine proteinase granzyme B to enter cells and induce the apoptosis of target cells. The mutated G8 repeat causes a premature stop codon and cytotoxic T cell mediated apoptosis of target cells is prevented. ${ }^{36}$ If apoptosis is prevented, cell growth is likely to be promoted.

Bloom's syndrome is a rare autosomal recessive disorder. The cells of BLM patients show genomic instability, and the patients have a high incidence of different cancers. BLM has DNA stimulated ATPase and ATP dependent DNA helicase activities. With RPA it is suggested to function in unwinding DNA during replication, recombination, or repair. ${ }^{37}$ The Blooms syndrome gene's (BLM) coding A9 repeat has been reported to be mutated in MSI positive colon cancer samples $(10 / 63=15.9 \%, 7 / 39=18 \%) .{ }^{20}{ }^{24}$ In this study, BLM was found to be mutated in 18 out of $93(19.4 \%)$ samples. When comparing this mutation rate of $B L M$ to intronic A9 repeats studied here, $B L M$ appeared as a true target gene $(p \leqslant 0.001)$. This finding is supported by the notion that Bloom's syndrome patients are predisposed not only to lymphomas and leukaemias, but also to colorectal tumours. ${ }^{38}$

\section{Novel candidate MSI target genes}

A total of 251 hits to genes with coding repeats were found by the MSI target gene search combined with keywords related to cancer, and 841 hits by search selecting for homology to 34 tumour suppressor or CRC related genes. Based on these two lists, publications were searched for interesting novel MSI targets. Three genes (BCL10, PTP-BAS, CtIP) and five genes (BAIl, P73, GIOT-2, PAIP, RIP3), respectively, were screened for mutations in mononucleotide repeats (table 2). Sequencing showed a significantly increased mutation rate in the A9 repeat in the middle of the CtIP gene $(25 / 109=22.9 \%)$. The frequency of CtIP A9 as compared with intronic A9 mutations was significantly different $(\mathrm{p} \leqslant 0.001)$. Second hits at CtIP shorter mononucleotide repeats (5-6 bp) were searched for but not found (data not shown).

The screened MSI positive CRC samples did not contain uniformly mutated MSI target genes or intronic repeats; indeed different samples contained individual mutations. Mutations in different samples seemed to occur randomly. Correlation between the clinicopathological characteristics and MSI target gene mutations ${ }^{18}$ as well as determining the spectrum of MSI target genes in a given cancer type could provide important insights into the malignant process. The tumour samples with CtIP mutation did not differ significantly from other MSI CRC samples. The degree of differentiation (grade I 16\%, II 52\%, III 28\%, IV 4\%) was similar to other MSI cancers $(8 \%, 72 \%, 20 \%, 0 \%$, respectively) and poorer as compared with MSS cancers in our whole population based 
Table 3 Previously proposed MSI target genes which contain exonic A9/T9 repeats (proportion of mutated MSI samples 10\% or more)

\begin{tabular}{|c|c|c|c|}
\hline $\begin{array}{l}\text { MSI target genes (exonic } \\
\text { A9/T9 repeat) }\end{array}$ & Mutations/samples & Reference & This study \\
\hline TCF4 & $19 / 49=39 \%$ & Duval et al ${ }^{15}$ & \\
\hline$R I Z$ & $8 / 24=33 \%$ & Chadwick et $a l^{17}$ & \\
\hline RAD50 & $13 / 39=33 \%$ & Kim et $a p^{24}$ & \\
\hline WISP-3 & $11 / 36=31 \%$ & Thorstensen et $a^{25}$ & \\
\hline $\begin{array}{l}\text { NADH-ubiquinone } \\
\text { oxidoreductase B } 14.5 B \\
\text { subunit }\end{array}$ & $12 / 43=28 \%$ & Mori et apo & \\
\hline KIAA0977 & $10 / 42=24 \%$ & Mori et $a^{p 6}$ & \\
\hline$C H I P$ & & & $25 / 109=22.9 \%$ \\
\hline GRK4/GPRK2L & $19 / 91=21 \%$ & Park et $a^{27}$ & \\
\hline \multirow[t]{2}{*}{$B L M$} & $10 / 63=16 \%$ & Calin et $a^{20}$ & \\
\hline & $7 / 39=18 \%$ & Kim et $a P^{24}$ & $18 / 93=19 \%$ \\
\hline CBF2 & $14 / 91=16 \%$ & Park et $a^{P^{7}}$ & \\
\hline KIAA0905 & $6 / 43=14 \%$ & Mori et $a^{26}$ & \\
\hline Exportin T & $6 / 43=14 \%$ & Mori et $a^{p 6}$ & \\
\hline RECQLI & $11 / 93=12 \%$ & Park et a ${ }^{27}$ & \\
\hline MCT & $4 / 36=11 \%$ & Mori et $a^{p 6}$ & \\
\hline ERCC5 & $8 / 80=10 \%$ & Park et $a^{P^{7}}$ & \\
\hline CHKI & $1 / 10=10 \%$ & Bertoni et $a l^{16}$ & \\
\hline
\end{tabular}

data set of 1044 CRCs $\left(22 \%, 69 \%, 9 \%, 0 \%\right.$, respectively). ${ }^{32}{ }^{33}$ The proportion of mucinous cancers was $20 \%, 21 \%$, and $8 \%$ in CtIP mutation positive CRC, other MSI positive CRC, and MSS lesions, respectively. The preference for mucinous and poorly differentiated histopathology in MSI lesions has been extensively documented previously by Kim et $a l^{39}$ and others. $^{8-10}$ The patients with and without somatic CtIP mutation had similar age distributions at the time of carcinoma diagnosis, and comparable site distribution with other MSI tumours; 19 CtIP mutated tumours out of 25 (76\%) were proximal, versus 68 out of $86(79 \%)$ in other MSI cases. Differing sex distribution was not observed (14 out of 49 in males versus 11 out of 60 in females).

CtIP was identified as a candidate from the search combined with keywords related to cancer. In the MSI positive CRC tumour samples, the $1 \mathrm{bp}$ deletion rate of $22.9 \%$ in the A9 repeat suggests that CtIP could be a new MSI target gene. Many of the suggested MSI target genes contain a mutable mononucleotide A9 repeat. As compared with other similar previously proposed MSI target genes, CtIP appears to be a reasonable candidate (table 3 ).

CtIP modulates transcriptional regulation, DNA repair, and cell cycle checkpoint control. CtIP has been found to associate with BRCAl, CtBPl, and Rb $1 .{ }^{40}$ ATM protein mutated in ataxia telangiectasia phosphorylates CtIP and so modulates BRCAl mediated regulation of the DNA damage response GADD45 gene. ${ }^{41}$ If CtIP is truncated, the association with the three tumour suppression activity proteins is likely to change. CtIP has not been found to be mutated in an earlier MSI target gene study. Ikenoue et $a l^{42}$ studied 13 primary colorectal tumours with high frequency of MSI, but no mutations were found in the mononucleotide repeat. ${ }^{42}$ If the CtIP mutation results from this study and that of Ikenoue et $a l^{42}$ are combined $(25 / 122=20.5 \%)$, the frequency of CtIP A9 and intronic A9 mutations remains significantly different $(p \leqslant 0.001)$.

Mismatch repair defective tumours display a mutator phenotype, in contrast to mismatch repair proficient colorectal tumours. Mismatch repair proficient tumours may also contain MSI target gene mutations, but because of the different biological backgrounds of the respective lesion types such absence of defects does not exclude the possibility of a real target gene. ${ }^{29}$ Thus the role of CtIP in microsatellite stable lesions was not evaluated in this work. In this study biallelic inactivation of CtIP (or any other gene) in MSI positive CRCs was not found, but the association with tumour suppression activity proteins may decrease by the reduced amount of CtIP. This might lead to a defect in the cellular response to DNA damage, and to tumorigenesis. By a similar mechanism heterozygous mismatch repair gene mutations appear to reduce the amount of gene products involved in the repair process. ${ }^{30}$ This alone may decrease replication fidelity. Also haploinsufficiency of the NSDl gene induces overgrowth in Sotos syndrome, implying that NSDl acts as a corepressor of genes that promote growth. ${ }^{43}$ Miyoshi et al ${ }^{44}$ have proposed that the initiation of polyposis in Peutz-Jeghers syndrome mouse model is not the result of biallelic loss of the Peutz-Jeghers syndrome gene $L k b l$. Gastrointestinal hamartomas appear to develop in heterozygous mice because of $L k b l$ haploinsufficiency.

It should be mentioned that in our study biallelic inactivation of CtIP might have been difficult to detect. We used primary tumours which contained some contaminating normal tissue. Microdissection, which would make detection of biallelic changes more feasible, was not applied. CtIP mutated MSI tumour cell lines would be useful in evaluating possible biallelic inactivation of this gene.

As compared with the mutation frequency cut off level for real MSI target genes proposed by Duval et al ${ }^{45}(12 \%)$, the observed CtIP mutation frequency $(22.9 \%)$ is of significance. Further work, such as functional analyses, is required to elucidate the importance of CtIP in the development of colorectal and other cancers.

\section{ACKNOWLEDGEMENTS}

We thank Anniina Leskinen and Annika Korvenpää for technical assistance. This study was funded by Finnish Culture Foundation, the Helsinki University Central Hospital, Biocentrum Helsinki, the Sigrid Juselius Foundation, the Finnish Cancer Society, and the Academy of Finland (44870, Finnish Centre of Excellence Program 2000-2005).

\section{Authors' affiliations}

S Vilkki, V Launonen, A Karhu, L A Aaltonen, Department of Medical Genetics, PO Box 63 (Haartmaninkatu 8), FIN-00014 University of Helsinki, Finland

P Sistonen, Finnish Red Cross Blood Transfusion Service, Kivihaantie 7 FIN-00310 Helsinki, Finland,

I Västrik*, Bioinformatics Core Facility, Biomedicum Helsinki, PO Box 63 (Haartmaninkatu 8), FIN-00014 University of Helsinki, Finland

\section{REFERENCES}

1 Leach F, Nicolaides N, Papadopoulos N, Liu B, Jen J, Parsons R, Peltomäki P, Sistonen P, Aaltonen L, Nyström-Lahti M, Guan XY, Zhang J, 
Meltzer PS, Yu JW, Kao FT, Chen DJ, Cerosaletti KM, Fournier REK, Todd $S$, Lewis T, Leach R J Naylor SL, Weissenbach J, Mecklin JP, Järvinen H, Petersen GM, Hamilton SR, Green J, Jass J, Watson P, Lynch HT, Trent JM, de la Chapelle A, Kinzler KW, Vogelstein B. Mutations of a mutS homolog in hereditary nonpolyposis colorectal cancer. Cell 1993:75: 1215-25

2 Fishel R, Lescoe M, Rao M, Copeland N, Jenkins N, Garber J, Kane M, Kolodner R. The human mutator gene homolog $\mathrm{MSH} 2$ and its association with hereditary nonpolyposis colon cancer. Cell 1993;75:1027-38.

3 Bronner C, Baker S, Morrison P. Warren G, Smith L, Lescoe M, Kane M, Earabino C, Lipford J, Lindblom A, Tannengård P, Bollag R, Godwin A, Ward D, Nordenskiöld M, Fishel R, Kolodner R, Liskay R. Mutation in the DNA mismatch repair gene homologue $\mathrm{hMLH} 1$ is associated with hereditary non-polyposis colon cancer. Nature 1994:368:258-61.

4 Papadopoulos N, Nicolaides N, Wei Y, Ruben S, Carter K, Rosen C, Haseltine W, Fleischmann R, Fraser C, Adams M, Venter J, Hamilton S, Petersen G, Watson P, Lynch H, Peltomäki P, Mecklin JP, de la Chapelle A, Kinzler K, Vogelstein B. Mutation of mutl homolog in hereditary colon cancer. Science 1994; 263:1625-9.

5 Nicolaides N, Papadopoulos N, Liu B, Wei Y, Carter K, Ruben S, Rosen C, Haseltine W, Fleischmann R, Fraser C, Adams M, Venter J, Dunlop M, Hamilton S, Petersen G, de la Chapelle A, Vogelstein B, Kinzler K. Mutations of two PMS homologues in hereditary nonpolyposis colon cancer. Nature 1994:371:75-80.

6 Miyaki M, Konishi M, Tanaka K, Kikuchi-Yanoshita R, Muraoka M, Yasuno $M$, Igari T, Koike $M$, Chiba M, Mori T. Germline mutation of MSH6 as the cause of hereditary nonpolyposis colorectal cancer. Nat Genet 1997; 17:271-2.

7 Peinado MA, Malkhosyan S, Velazquez A, Perucho M. Isolation and characterization of allelic losses and gains in colorectal tumors by arbitrarily primed polymerase chain reaction. Proc Natl Acad Sci USA 1992;89: 10065-9.

8 Ionov Y, Peinado M, Malkhosyan S, Shibata D, Perucho M. Ubiquitous somatic mutations in simple repeated sequences reveal a new mechanism for colonic carcinogenesis. Nature 1993;363:558-61.

9 Aaltonen LA, Peltomäki P, Leach F, Sistonen P, Pylkkanen L, Mecklin JP, Jarvinen $\mathrm{H}$, Powell SM, Jen J, Hamilton SR, Petersen GM, Kinzler KW, Vogelstein B, de la Chapelle A. Clues to the pathogenesis of familial colorectal cancer. Science 1993;260:812-16.

10 Thibodeau SN, Bren G, Schaid D. Microsatellite instability in cancer of the proximal colon. Science 1993;260:816-19

11 Parsons R, Myeroff LL, Liu B, Markowitz SD, Kinzler KW, Vogelstein B. Microsatellite instability and mutations of the transforming growth factor beta type II receptor gene in colorectal cancer. Cancer Res 1995:55:5548-50

12 Souza R, Appel R, Yin J, Wang S, Smolinski KN, Abraham JM, Zou T, Shi Y, Lei J, Cottrell J, Cymes K, Biden K, Simms L, Leggett B, Lynch PM, Frazier M, Powell SM, Harpaz N, Sugimura H, Young J, Meltzer SJ. Microsatellite instability in the insulin like growth factor II receptor gene in gastrointestinal tumors. Nat Genet 1996;14:255-7.

13 Rampino Y, Yamamoto H, lonov Y, Li Y, Sawai H, Reed J, Perucho M. Somatic frameshift mutations in the BAX gene in colon cancers of the microsatellite mutator phenotype. Science 1997; 275:967-9.

14 Malkhosyan S, Rampino N, Yamamoto H, Perucho M. Frameshift mutator mutations. Nature 1996:382:499-500.

15 Duval A, Gayet J, Zhou XP, lacopetta B, Thomas G, Hamelin R. Frequent frameshift mutations of the TCF-4 gene in colorectal cancers with microsatellite instability. Cancer Res 1999;59:4213-15.

16 Bertoni F, Codegoni AM, Furlan D, Tibiletti MG, Capella C, Broggini M. $\mathrm{CHK} 1$ frameshift mutations in genetically unstable colorectal and endometrial cancers. Genes Chrom Cancer 1999;26:176-80.

17 Chadwick RB, Jiang GL, Bennington GA, Yuan B, Johnson CK, Stevens MW, Niemann TH, Peltomaki P, Huang S, de la Chapelle A. Candidate tumor suppressor RIZ is frequently involved in colorectal carcinogenesis. Proc Natl Acad Sci USA 2000:97:2662-7.

18 Bader S, Walker M, Hendrich B, Bird A, Bird C, Hooper M, Wyllie A. Somatic frameshift mutations in the MBD4 gene of sporadic colon cancers with mismatch repair deficiency. Oncogene 1999;18:8044-7.

19 Calin G, Herlea V, Barbanti-Brodano G, Negrini M. The coding region of the Bloom syndrome BLM gene and of the CBL proto-oncogene is mutated in genetically unstable sporadic gastrointestinal tumors. Cancer Res 1998; $58: 3777-81$

20 Calin G, Gafa R, Tibiletti MG, Herlea V, Becheanu G, Cavazzini L, Barbanti-Brodano G, Nenci I, Negrini M, Lanza G. Genetic progression in microsatellite instability high (MSI-H) colon cancers correlates with clinico-pathological parameters: a study of the TGF $\beta \mathrm{RII}, \mathrm{BAX}, \mathrm{HMSH} 3$, HMSH6, IGFIIR and BLM genes. Int J Cancer 2000;89:230-5.

21 Schwartz S, Yamamoto H, Navarro M, Maestro M, Reventos J, Perucho M. Frameshift mutations at mononucleotide repeats in Caspase-5 and other target genes in endometrial and gastrointestinal cancer of the microsatellite mutator phenotype. Cancer Res 1999;59:2995-3002.

22 Guanti G, Resta N, Simone C, Cariola F, Demma I, Fiorente P, Gentile $M$. Involvement of PTEN mutations in the genetic pathways of colorectal carcinogenesis. Hum Mol Genet 2000:9:283-7.

23 Yamamoto H, Gil J, Schwartz S Jr, Perucho M. Frameshift mutations in Fas, Apaf-1 and Bcl-10 in gastro-intestinal cancer of the microsatellite mutator phenotype. Cell Death Differ 2000;7:238-9.

$24 \operatorname{Kim}$ NG, Choi Y, Baek M, Kim Y, Kang H, Kim N, Min J, Kim H. Frameshift mutations at coding mononucleotide repeats of the hRAD50 gene in gastrointestinal carcinomas with microsatellite instability. Cancer Res 2001;61:36-8.
25 Thorstensen L, Diep C, Meling G, Aagesen T, Ahrens C, Rognum T, Lothe R. WNTI inducible signaling pathway protein 3, WISP-3, a novel target gene in colorectal carcinomas with microsatellite instability. Gastroenterology 2001:121:1275-80.

26 Mori Y, Yin J, Rashid A, Leggett B, Young J, Simms L, Kuehl P, Langenberg P, Meltzer S, Stine O. Instabilotyping: comprehensive identification of frameshift mutations caused by coding region microsatellite instability. Cancer Res 2001;61:6046-9.

27 Park J, Betel D, Gryfe R, Michalickova K, Nicola N, Gallinger S, Hogue C, Redston M. Mutation profiling of mismatch repair-deficient colorectal cancers using an in silico genome scan to identify coding microsatellites. Cancer Res 2002;62:1284-8.

28 Boland CR, Thibodeau SN, Hamilton SR, Sidransky D, Eshleman JR, Burt RW, Meltzer SJ, Rodrigues-Bigas MA, Fodde R, Ranzani GN, Srivastava S. A National Cancer Institute workshop on microsatellite instability for cancer detection and familial predisposition: development of international criteria for the determination of microsatellite instability in colorectal cancer. Cancer Res 1998;58:5248-57.

29 Perucho M. Correspondence re: C R Boland et al. A National Cancer Institute workshop on microsatellite instability for cancer detection and familial predisposition: development of international criteria for the determination of microsatellite instability in colorectal cancer, Cancer Res 1998;58:5248-57. Cancer Res 1999;59:249-56.

30 Ohmiya N, Matsumoto S, Yamamoto H, Baranovskaya, Malkhosyan S, Perucho M. Germline and somatic mutations in hMSH6 and hMSH3 in gastrointestinal cancers of the microsatellite mutator phenotype. Gene 2001;272:301-13.

31 Zhang L, Yu J, Willson JKV, Markowitz SD, Kinzler KW, Vogelstein B. Short mononucleotide repeat sequence variability in mismatch repair-deficient cancers. Cancer Res 2001;61:3801-5.

32 Aaltonen LA, Salovaara R, Kristo P, Canzian F, Hemminki A, Peltomäki P, Chadwick RB, Percesepe A, Kääriäinen $\mathrm{H}$, Ahtola $\mathrm{H}$, Eskelinen $M$, Härkönen N, Julkunen R, Kangas E, Ojala S, Tulikoura J, Valkamo $E$, Järvinen $H$, Mecklin JP, de la Chapelle A. Incidence of hereditary nonpolyposis colorectal cancer, and molecular screening for the disease. N Engl J Med 1998:338:1481-7.

33 Salovaara R, Loukola $A$, Kristo $P$, Kääriäinen $H$, Ahtola $H$, Eskelinen $M$, Härkönen N, Julkunen R, Kangas E, Ojala S, Tulikoura J, Valkamo E, Järvinen $\mathrm{H}$, Mecklin JP, Aaltonen LA, de la Chapelle A. Population-wide molecular detection of hereditary nonpolyposis colorectal cancer. J Clin Oncol 2000:18:2193-200.

34 Suzuki K, Dai T, Suzuki I, Dai Y, Yamashita K, Perucho M. Low mutation incidence in polymorphic noncoding short mononucleotide repeats in gastrointestinal cancer of the microsatellite mutator phenotype pathway. Cancer Res 2002;62:1961-5.

35 Ouyang H, Shiwaku HO, Hagiwara H, Miura K, Abe T, Kato Y, Ohtani $H$, Shiiba K, Souza RF, Meltzer SJ, Horii A. The insulin-like growth factor II receptor gene is mutated in genetically unstable cancers of the endometrium, stomach, and colorectum. Cancer Res 1997:57:1851-4.

36 Motyka B, Korbutt G, Pinkoski M, Heibein JA, Caputo A, Hobman M, Barry M, Shostak I, Sawchuk T, Holmes CFB, Gauldie J, Bleackley RC. Mannose 6-phosphate/insulin-like growth factor II receptor is a death receptor for granzyme B during cytotoxic T-cell-induced apoptosis. Cell 2000; 103:491-500.

37 Brosh RM, Li JL, Kenny MK, Karow JK, Cooper MP, Kureekattil RP, Hickson ID, Bohr VA. Replication protein A physically interacts with the Bloom's syndrome protein and stimulates its helicase activity. J Biol Chem 2000; $275: 23500-8$

38 Lowy AM, Kordich JJ, Gismondi V, Varesco L, Blough RI, Groden J. Numerous colonic adenomas in an individual with Bloom's syndrome. Gastroenterology 2001;121:435-9.

$39 \mathrm{Kim} \mathrm{H}$, Jen J, Vogelstein B, Hamilton SR. Clinical and pathological characteristics of sporadic colorectal carcinomas with DNA replication errors in microsatellite sequences. Am J Pathol 1994;145: 148-56.

40 Yu X, Baer R. Nuclear localization and cell cycle-specific expression of CIIP, a protein that associates with the BRCA1 tumor suppressor. J Biol Chem 2000;275: 18541-9

41 Li S, Ting NS, Zheng L, Chen PL, Ziv Y, Shiloh Y, Lee EY, Lee WH Functional link of BRCA1 and ataxia telangiectasia gene product in DNA damage. Nature 2000:406:210-15.

42 Ikenove T, Togo G, Nagai K, ljichi $\mathrm{H}$, Kato J, Yamaji Y, Okamoto M, Kato N, Kawabe T, Tanaka A, MatsumuraM, Shiratori Y, Omata M Frameshift mutations at mononucleotide repeats in RAD50 recombinational DNA repair gene in colorectal cancers with microsatellite instability. Jpn J Cancer Res 2001;92:587-91.

43 Kurotaki N, Imaizumi K, Harada N, Masuno M, Kondoh T, Nagai T, Ohashi H, Naritomi K, Tsukahara M, Makita Y, Sugimoto T, Sonoda T, Hasegawa T, Chinen Y, Tomita H, Kinoshita A, Mizuguchi T, Yoshiura K, Ohta T, Kishino T, Fukushima Y, Niikawa N, Matsumoto N Haploinsufficiency of NSD 1 causes Sotos syndrome. Nat Genet 2002;30:365-6

44 Miyoshi H, Nakau M, Ishikawa T, Seldin MF, Oshima M, Taketo MM. Gastrointestinal hamartomatous polyposis in $\mathrm{Lkb} 1$ heterozygous knockou mice. Cancer Res 2002;62:2261-6.

45 Duval A, Rolland S, Compoint A, Tubacher E, lacopetta B, Thomas G, Hamelin R. Evolution of instability at coding and non-coding repeat sequences in human MSI-H colorectal cancers. Hum Mol Genet 2001;10:513-18. 